\title{
Of Other Spaces, of Other Times - Towards New Materialist Politics of Squatting
}

\author{
Monika Rogowska-Stangret ${ }^{*}$ \\ Received February 2015; accepted June 2015; published Summer 2015.
}

\begin{abstract}
In the article the author reflects on the meaning of politics in a newmaterialist framework. She concentrates predominantly on two political dimentions - space and time. With reference to that, the author develops the concept of politics of squatting. Its spatial aspect is investigated along the lines of the notion of heterotopia, coined by Michel Foucault, and its temporal aspect is analyzed through the concept of heterochrony (Foucault) and Darwinian evolution as interpreted by Elizabeth Grosz. The concept of politics of squatting is then juxtaposed with nomadism (vide Rosi Braidotti). Finally, the author provides a case study by elaborating on the anti-gender campaign that began in 2012-2013 in Poland from the perspective of politics of squatting.
\end{abstract}

Keywords: rationality; objectivity; modern science; gender; gender problem in science.

\section{Introduction}

The recognition of the fact that knowledge, science, onto-epistemological understanding of the world is neither neutral, nor a pure act of conceptualization may be traced back to the work of Friedrich Nietzsche and later to Michel Foucault and his influential concept of power/knowledge. Feminist philosophers dwelled on this very link, developing the concepts that explicitly diagnosed mutual entanglement between politics and knowledge ${ }^{17}$. In the relatively new trend in feminist philosophy called "new materialism" ${ }^{18}$ and developed

\footnotetext{
${ }^{*}$ PhD at the Institute of Philosophy and Sociology, Polish Academy of Sciences, Warsaw

${ }^{17}$ One of the most explicit examples of such a trend in feminist scholarship is the notion of "situated knowledges” coined by Donna Haraway in her famous article: Haraway 1988.

${ }^{18}$ It is not my aim in this article to define "new materialism”. I would like to direct readers' attention to existing literature on the question of definition of the mentioned trend. See for example Coole, Frost 2010: 1-43 or Dolphijn, van der Tuin 2012.
} 
since the mid 90. the interrelatedness between what is political and what is conceptualized became an obvious field of philosophical investigation. For thinkers such as Karen Barad, Rosi Braidotti, Elizabeth Grosz, Vicki Kirby, Erin Manning or Brian Massumi ${ }^{19}$ the political (in some cases if not in all, accompanies by the ethical) lies in the heart of their philosophical, ontoepistemological projects. It is mostly due to the fact that the aforementioned philosophers force us to rethink the ethical-political notions of subject, agent, action and relation anew by elaborating on the concepts such as matter, body, relation, agency. Who is the subject in the posthuman world? Who may act and how agency may be understood? How may we conceive of relation in the quantum reality and how may it influence the sphere of the ethical and the political? What are the ethical and political consequences of the notion of naturecultures? "What [do] animals teach us about politics?" How can we envision ethics and politics along the lines of "leaky sense of self"? These are just some questions that may be raised in response to some of the concepts of new materialist philosophers. Simultaneously, the way certain concepts (like body, matter, agency etc.) are developed reveals its dependence on a specific ethicopolitical stance. So, not only do new conceptual reformulations demand or imply ethical and political transformations, but also ethico-political standpoints, preferences or tendencies direct thinkers to certain way of doing philosophy, choosing subjects of inquiry and approaching philosophical notions. The two "orders" - onto-epistemological and ethico-political - are embedded in one another, imply one another and thus cannot be analyzed apart.

The theoretical achievements of new materialist thinkers do not serve as a famous "box of tools" as it was previously envisioned by Michel Foucault and Gilles Deleuze in their talk entitled Intellectuals and Power (Deleuze, Foucault 2006). What is at stake here, as I believe, is the question of thinking, envisioning and conceptualizing subjects, actions, and relations anew in their direct connection to political and ethical endeavors. The theoretical struggles become practical struggles at once. Questions such as: how to do this? how to achieve that? are just other ways of asking: how to think about it? how to grasp that intellectually? Theoretical concepts change the frames that limit, define or enable our actions.

The ideas enlivened in new materialist theoretical frameworks obligate us to rethink the very frames that make the action of the subject possible, worthwhile, purposeful, efficient or competent. Theoretical apparatus determines who may be understood as subject and who may not. And moreo-

\footnotetext{
${ }^{19}$ Not all the philosophers mentioned here would gladly accept the label "new materialism" as characterizing their own work. Elizabeth Grosz has expressed her doubts in: Grosz 2011: 5. Erin Manning and Brian Massumi are usually described as empirical pragmatists. But still their ways of conceptualization resonate strongly with "new materialisms" as described in the literature mentioned which is proven by their presence in broadly understood "new materialist" debates.
} 
ver, the theory circumscribes the meaningful political and ethical relations while negating the allegedly irrelevant. I shall exemplify this line of thinking with two instances.

First of all, to illustrate the theory-politics (practice) connection, let me mention Elizabeth Grosz and her statement about the link between ontology and politics:

The intellectual understanding of what one does institutionally, [...] commits you to an ontology. [...] It's an ontology about what categories exist, what categories are necessary to define one's world, and they of course shift depending on what your political position is (Grosz, Cheah 1998: 32).

To grasp the "es-sence" of what we do politically means in fact to uncover the ontology that lies behind it. This ontology has a crucial meaning for our political emplacement, it indicates our position, defines our battles, and conceptualizes how we comprehend the world we live in. That means also that any theoretical, ontological shifts are already political transformations. Thus ontology and political position are interwoven to the extent that they are just two sides of one coin.

Secondly, to depict the entanglement between knowledge (theoretical apparatus) and being (the world, practices, subjects, objects etc.), I would like to direct the readers' attention to the work of Karen Barad and her remarks on onto-epistem-ology - "the study of practices of knowing in being" (Barad 2003: 829). Barad states:

[...] apparatuses are the exclusionary practices of mattering through which intelligibility and materiality are constituted. Apparatuses are material (re)configurings/discursive practices that produce material phenomena in their discursively differentiated becoming (2003: 820).

Thus, we did not have a clear-cut distinction between theoretical framework and the world out there. Hence, processes of knowledge production perform their discursive materiality (the world, phenomena, intra-actions) and our theoretical approach is an integral part of the world entanglements.

The question thus is: How to imagine new frames that would meet the demands of political-ethical struggles that open up the world to its diverse corporeal forms, varied ways of life, and modes of acting?

In this article I would like to concentrate on two dimensions of the mentioned frames, namely time and space. How to interact with space and time to fulfill some ethical and political challenges of contemporary worlds? How can we address the questions of tensions between past, present, and future, the problem of novelty, change, transformation, and its entanglement with temporal dimensions? How to investigate into spatial aspects of politics? What are the links between subjects, their naturecultures, biotechnological environment, 
and other subjects or agents? How can we situate ourselves in a dense body of varied political strategies, visions, and ideas? How can we relate ourselves to diversified theories, discourses, and points of view? What kind of attitude can we develop in relation with broadly understood others? How to articulate one's standpoint within a density of other propositions? How to open up the given orders to the new?

\section{Squatting}

To face these questions, I suggest viewing them from the perspective of politics of squatting. When I started working on the concept of politics of squatting, I treated squatting merely as a metaphor, a model useful for conceptualization of space and time as two dimensions of politics. After feedback I received at the $5^{\text {th }}$ New Materialist Conference in Barcelona ${ }^{20}$, I understood that my aims are twofold. On the one hand, I still see the practice of squatting as a metaphor useful to grasp the mechanism of creating and producing the time and space for the new. On the other hand however, I see politics of squatting as a way to rethink the practice of both squatting and political action.

Squatting is a metaphor or a model that appeals to me for at least four reasons.

First of all, it brings together spatial and temporal aspects of political action. It consists in searching for a space, where an individual or a collective could dwell, work, and feel safe. But simultaneously it has a timely dimension: it uses a space with a given past to de(re)construct it, give it another meaning, transform its present, and give it some kind of future. By that politics of squatting attests to the fact of spatio-temporal performative entanglements as a core dilemma for politics.

Secondly, it is a model that acts in an un-empty environment, thus it enroots subjects in a given context that cannot be simply omitted, ignored or obliterated. That means attesting to two assumptions. On the one hand it acknowledges the fact that squatting agents are constituted in relation to their own history, space location, social background, and existential situation. On the other hand, the world in which, of which and upon which they are acting is also intermingled with its past, present, future, location, situation, materiality. That means that agents and their environment, the world they live in, may never be perceived as a kind of tabula rasa. It is due to the fact that they are material - their time and space leave traces in the matter of the agent and his or her world. What is more, there is no distinct separation between the subject and her environment, they interact, influence each other, and form each

\footnotetext{
${ }^{20}$ New Materialist Methodologies: Gender, Politics, the Digital, V Annual Conference on the New Materialisms, Barcelona, Spain, 25th-26 $6^{\text {th }}$ September 2014.
} 
other. Just like in the example provided by Jacob von Uexküll: the spider, the spider web and the fly, where each element is related to others in such a way that they evolve together and not in isolation from one another (von Uexküll 2010: 190n).

I see politics of squatting as a form of "politics of location" described by Adrienne Rich (Rich 1986). However "politics of location" here is not understood as recognizing subject's location in the world, rather it is understood as grasping "dynamic (re)configurings of the world" (Barad 2003: 816), where the sharp distinction between the subject and her position in the world does not exist, bringing instead the notion of interconnectedness of various factors (human-non-human, animal, plant, organic-in-organic, environmental, biotechnological, etc.).

Thirdly, squatting demands a close observation of the body of the city, finding the unused and forgotten sites that may be re-used, that are open towards new meanings, that somehow resonate with the future. Thus, the squatting agent needs a place that gives her materiality to be used in a new, unexpected way, to be re-build, de(re)construct. This is not a situation where we can build our world from the very beginning, design it on an empty building site, think about it as if we have never already been in and of the world, and imagine rules under the veil of ignorance. Squatting needs negotiating, taking into consideration what already exists, and entering into a dialogue with different orders and discourses.

Fourthly, politics of squatting is first and foremost about acting and not about being. The very act of squatting is central here and not the question of who (what kind of subject) performed it. Placing action in the heart of politics, instead of subject, has its roots in contemporary feminist work and enters into a dialogue with the concept of performativity used by Judith Butler in her notion of "politics of the performative" (Butler 1997), with the recent critique of the notion of "identity politics" by Elizabeth Grosz (2011: 71-89), who stressed that the current problem of feminist theory lies not in "more adequate recognition (who is it that women require recognition from?), more rights, or more of a voice", but in coming up with the possibilities "to enable more action, more making and doing, more difference" (2011: 73). That makes it clear that in Grosz's vision of the political it is about acting, doing, performing and not about being recognized as a subject of rights. This tendency is also present in the work by Karen Barad and her critique of represenationalism from the performative perspective (2003: 801-831), which shifts the political interests toward "matters of practices/doings/actions".

To analyze politics of squatting in more detail, I would like to elaborate on its spatial aspect with reference to Michel Foucault's concept of heterotopias and on its temporal aspect by diffracting Foucault's notion of heterochrony with Elizabeth Grosz's reinterpretation of Darwinian evolution. I will 
also remark on the comparison between nomadism and squatting presenting politics of squatting as an alternative. Finally, I will briefly sketch the Polish context of recent anti-gender campaign trying to analyze it in terms of politics of squatting.

\section{Of other spaces}

Squatting is about longing for other spaces. Longing has a strong temporal dimension and I will elaborate on time further on. Let us concentrate on space.

In his famous article Of Other Spaces: Utopias and Heterotopias (Foucault 1984) Michel Foucault recognized $20^{\text {th }}$ century as an "epoch of space", where the space is understood as a "form of relations among sites" and the crucial spatial aspect is emplacement. As the philosopher stated:

[...] we do not live in a kind of void, inside of which we could place individuals and things. We do not live inside a void that could be colored with diverse shades of light, we live inside a set of relations that delineates sites which are irreducible to one another and absolutely not superimposable on one another (Foucault 1984:3).

In this settings there emerge heterotopias - sites that are "in relation with all the other sites, but in such a way as to suspect, neutralize, or invent the set of relations that they happen to designate, mirror, or reflect". Heterotopias are real places, "counter-sites", "effectively enacted utopias", or "other (real) spaces" that represent, contest, and invert real spaces. I suggest viewing squatting as an activity devoted to creating heterotopias.

According to Foucault, there are six principles of heterotopias, the majority of which may be referred to squats. Probably not every culture in the world has developed forms of squatting, but the phenomenon is popular in lots of places in the world (including Europe, Africa, North and South America, Asia, Oceania, and Australia ${ }^{21}$ ). The idea of squatting (thus underlining the action) exceeds the limitations of the (human) subject (or identity) oriented politics. It may well be expanded to engage with posthuman or nonhuman subjects. We could perceive non-human animals, plants, organic and inorganic forms as squatters. Just think of an animal (be it a dog, cat, spider, bird, ant etc.), who searches for the place for their nest, web, lodge or any other type of home we may think of. Just recall minerals embedded in ordinary rocks or stones. Or visualize plants blossoming suddenly in apparently unfriendly habitat.

\footnotetext{
${ }^{21}$ See: URL = <http://en.wikipedia.org/wiki/Squatting>, 5.01.2015.
} 
The society may change squats' functions - it may be seen as an alternative form of housing, cultural or political center, or illegal practice. Squat as heterotopia is a single real place that is capable of combining several sites - living and working spaces of different actors, sites of political engagement or cultural activity - which is in itself multispatial etc. Squats also bring into existence heterochronies - not in the sense of accumulating time (like museums) or cherishing the transitoriness of time of festival, but with reference to time as directed towards the future, towards novelty and the unexpected. Squats, just like heterotopias, have their system of opening and closing - they have internal rules regulating it. And finally, they may have a function in relation to space outside squat - be it for instance the crime scene or a lived utopia.

Squats as heterotopias are the spheres that combine a real existence (contrary to utopias) with contestation, inversion or dialogue with rules, norms, and principles governing the space outside them. Moreover, they bring into existence not only other spaces, but also other times and they enliven the longing I mentioned before. Heterochrony that emerges in a squat provides Foucault's take on heterochrony with yet another dimension. The French philosopher is preoccupied with the eternal dimension (accumulating time) and temporal dimension (the transitoriness of time), whereas squatting mobilizes the two to meet in the act of longing or the dimension of hope. The time of hope is fuelled by the accumulation of moments but it is deprived of its claims to eternity. These are seen as volatile and transient. Between the urge to preserve eternity and the state of the evanescent movement of time, the gap emerges. This gap is where the longing appears and where the time of hope may rise, it is filled with excitement, joy, plans, daydreaming, energy, play, the feeling that only sky is the limit and the one we may easily transcend. To grasp the time of hope I will turn to another time conceptualization that seems to connote this one.

\section{Of other times}

Squatting is about longing for other times. Elizabeth Grosz claimed: “(...) to the extent that all radical politics is implicitly directed towards bringing into existence a future somehow dislocated from the present, our very object and milieu is time" (2010: 51). In this view heterochrony would be some other time, time as milieu, where the entanglement between past, present, and future emerges, and is dislocated into or opened up towards the unforeseeable future.

Grosz in her book The Nick of Time interprets evolution as a kind of mechanism that reworks the past into the present and the future. Past living beings serve as "the raw material" for the new ones without overwhelmingly limiting or determining them. The philosopher states: 
The movement of evolution is in principle unpredictable, which is to say that it is historical: related species in the past prefigure and provide the raw material for present and future species but in no way contain or limit them. [...] The present and future diverge from the past: the past is not causal element of which the present and future are given effects but the ground from which divergence and difference erupt (2004: 8).

Evolution conceptualized in this manner has also a political dimension. Whatever there was in the past (traumas, exclusions, achievements, joys etc.) may be reworked, renewed, and reinterpreted. It is open for future transformations and changes, it is not determining what is to come while serving as a ground for it to come, while enabling it.

In a similar vein I would like to see squatting as an activity that acts on time and in time (as a milieu) using its potential. The past (of the space, building, place, living beings, things, life etc.) is directed into a new present and future. The present and the future are influenced by the past to some extent, but simultaneously they are oriented toward what is new, undetermined by past condition, function, goal etc., and even unthought-of. This openness towards the future is twofold. On the one hand, there is risk attached - the opening - taken seriously - does not involve any closing (predicting, establishing beforehand etc.) whatsoever. Thus it may be harmful, threatening, it reveals the shared vulnerability of engaged bodies. On the other hand however, it opens up the space for experiment, excess, inventiveness, joy and play ${ }^{22}$.

\section{Nomadism and squatting}

The concept of squatting and the figure of a squatter may evoke nomad as a conceptualization of the subject and nomadism as a political project by Rosi Braidotti (Braidotti 1994). The practice of squatting, as was previously stated, is about acting not acting agent, but that does not mean that the concept of the subject is omitted here. Squatting envisions certain concept of a dynamic, relational, acting, corporeal ${ }^{23}$ agency or subjectivity. It is transitory, unstable, fluid. It is more like a net of varied, diverse factors (of different "natures" and genealogies) that operate in a swarm-like or rhizome-like manner, that intermingle, interact, influence each other, and act together.

\footnotetext{
${ }^{22}$ For further elaboration on excess in evolution and sexual selection as excess see Grosz 2004, 2005, 2011 and to grasp in-depth the force of play implied in animal politics see Massumi 2014. The dimension of excess was applied in the artistic work by Pinar Yoldas in her project „An Ecosystem of Excess", where she grasps both the playful, excessive aspect of transformation towards the new and the threats and risks attached. By that she provides us with recognizing ambiguity of openness that consist in being both overwhelmed with beauty and new possibilities and frightened or even endangered, cheerful and bewildered. For more information on the project see: http://www.pinaryoldas.info/.

${ }^{23}$ I understand the notion “corporeal” as conceptualized in Grosz 1987: 1-15 and Grosz 1994.
} 
Both a nomad and a squatter challenge and undermine limitations and all kinds of borders and oppositions (e.g. public-private, same-other, us-them, etc.). They cannot be perceived as homeless as they can set up home everywhere. Moreover, the subject in question (a nomad or a squatter) is transitory, lacks any kind of stability. Indeed, squatting is a gap, a between, an interlude.

Braidotti is clear about the fact that nomads do have history. In her own practice of writing philosophy she is positioning herself as a nomad and highlighting her own genealogies, cartographies, positions. Thus, Braidotti mentions the past of a nomad, the fact that she is situated and located in the world in a very concrete existential, material, historical, environmental, biological, sexual situation. However explicit this may be, I frequently succumb to an illusion. Namely, it sometimes strikes me in Braidotti's account of nomadism that it occasionally seems as if a nomad would have no past, no location, no class, only the present moment - unlimited, multilayered, and uncertain, from which she can delineate her position. Probably, the reason for this obvious misunderstanding is the fact that Braidotti does not provide us with an understanding of how the past may be reworked, how the concrete subject position in the world may be conceived in terms of fluidity of a nomad, how the history may not be limiting or determining, and how the location of the subject may not determine her.

The squatter is different. The squatter is faced with the past, stability, fixed identity - not only of herself but also of her environment, settings, the world. She is enrooted in her past, even if the past is rich, polymorphous, and multiple. People she met, books she read, conversations she heard, histories of people who were here before - in the houses, where the squatter dwells in now, their ways of life, their dreams, fears, hopes and joys - she is embedded in all this. Transitoriness of the squatter lies in her future and in the way she will treat her past.

Starting from the past position, the squatter searches for a gap, intermezzo, space and time in-between. In this way the squatter opens up her past for future instability, reworks the past, enters into a dialogue with the past forms of life, identities, and consequently they become deprived of their power to determine the present and the future.

The squatter has a sex, a class, certain social background, history, place of birth, parents (even if they never met), love ones, friends, a look, a body of certain color, shape, ability, the history of her country/ies is influencing her, she has her ancestors etc. In a way, however, the subject position is a misnomer, a shorthand that conceal "the amalgamation of a series of tendencies and proclivities, the cohesive point at which a multiplicity of potentialities resolves as this or that event of experience" (Manning 2013: 16). What makes her a squatter is the will to open up for a transitory future, unstable, uncertain, 
unforeseeable, unthought-of, unknown, to reveal the fact of being more than one, multiplicity, rhizome, assemblage, transindividuation, constellation.

\section{Case study}

There are plenty of examples of politics of squatting and also plenty of cases to come. To mention one of them I will shortly describe my visit to Serbia. When I was in Belgrade in early December 2014, I encountered squatters that occupied the cinema "Zvezda". The reason for this action was the fact that the cinema was closed for a long time, there were even plans to replace the movie theater with a commercial space and finally the initiators of the action wanted to enliven the space, to make it a place of culture again. To this end, squatters occupied the building, the free of charge screenings were organized (the public was invited to co-create the programme), and the renovation of the building was initiated ${ }^{24}$.

However accurate the Serbian case study may seem, I would like to concentrate on the recent anti-gender campaign in Poland as it unveils other layers of conflicts in Polish society that may be viewed from the perspective of the politics of squatting. The provided analysis remains open and presents only one possible way of approaching the conflict site. It aims at mobilizing other perspectives, points of view, voices and is designed to infect readers with the urge to engage in the debate to enrich it by presenting the anti-gender movement in Poland as complex assemblage with various traits and lines of interpretations.

In the years 2012-2013 ${ }^{25}$ there occurred an attack against "gender" performed by "conservatists" (Catholic fanatics) and boosted in heated media discussions. Fanatics claimed that gender forms "the ideology of gender" that depraves “'our' children and is unhealthy for 'our' (Polish, traditional) families" and that threatens Polish, Catholic traditional values, models of family and gender roles. Several protests against various gender equality programs were organized and the parliament group fighting “ideology of gender” was established. Importantly, gender as a word of English origin (by that I obviously do not mean etymological origin, but only the fact that it came to Poland as a result of "gender studies" evolving in the Western countries) could mean anything, because it was not embedded in Polish language, it lacked connotations and associations with other phrases and expressions. It became a sort of an empty word one may fill with any sense whatsoever. From the most radical perspective "gender" was presented as a symbol of Satan, more generally - a symbol of everything - Polish people might be frightened of.

\footnotetext{
${ }^{24}$ The information concerning the squatting of cinema "Zvezda" was obtained during a private conversation with the squatters.

${ }^{25}$ For a more thorough description of the anti-gender movement in Poland and beyond see Kováts, Põim 2015.
} 
This attack on gender (and, in consequence, on queer and even "animal studies") may be perceived as an expression of hate, xenophobia, fears of the other - it manifests sometimes (in different context) in words such as "gay propaganda", "to be infected with homosexuality", and in bodily disgust and fear of being contaminated with disease, virus, something strange that is perceived as danger and threat against one's identity.

This diagnosis seems convincing, yet the fear of the other, of the strangeness, of uncanniness, may have unobvious genealogies, hidden labyrinths, and seemingly dead ends.

A Polish philosopher and psychoanalyst - Andrzej Leder - recently wrote a book that provides us with one possible interpretation of what is hidden behind the fear and how it may be understood in the context of Polish history. Leder writes about the revolution that was not reworked in the Polish imaginarium, in the "psychic life" of Polish society (2014:7-25). The revolution, as Leder claims, took place from 1939 to 1956 and had a major impact on the Polish society. As Leder points out, one of its consequences was creating a space for the Polish middle class to appear and develop. The researcher provides us with his interpretation of how the social relations looked like before and after the World War II. Polish society before the war was generally concentrated in the countryside and not in the cities. Polish class structure did not have its own middle class, instead there were peasants and nobility (upper classes). Middle class was formed by Polish Jews. So the possibility to form middle class in Poland arose when Jews were exterminated during the World War II, because Polish peasants took over the Jewish shops, houses and properties and started a new life from this moment on - not as peasants but as middle class. All of these happened unnoticed. It "just" happened as if Polish society played a passive role in the whole process, as if they were deprived of agency, willingness, and the opportunity to make a decision, as if they were merely victims of war crimes. The problem was that Polish society came from different background, it did not have middle class imaginarium, and, moreover, it was established on the suffering and harms of others without acknowledging that. It was never psychoanalytically reworked, it is hard nowadays to talk about Polish crimes against Jews and about the fact that all of us stem from these very phenomena. We might have not oppressed Jews personally, but simply use what was left by them (Grabowski, Libionka 2014). The fact that Jews were out of the picture enabled considerable parts of the Polish society to acquire a subject position, a position of active agents (Leder 2014: 91). What is especially useful and convincing in Leder's analyses, at least from my perspective, is how he applies psychoanalytical tools to develop his thoughts on class dynamics and social transformations in Poland. In doing so, he succeeds at engaging both space and time into his historicalphilosophical elaboration. 
Squatting the Jewish property may look like the politics of squatting but it is not. This is mainly due to the fact that the politics of squatting links and embraces both political dimensions - space and time. In the analyzed circumstances, the space was indeed domesticated, squatted, re-used, even dominated or colonialized, but the temporal perspective was obliterated. The past was blurred, ousted, and repressed. The past harms, joys, relationships were covered under the powerful will to posit oneself as a subject. We have never faced the past, embraced it or squatted it to make it open towards the future. Instead, the temporal aspect was transformed to a repressed nightmare that haunts us in silence, unconsciously, whisperingly. The erasure of the dimension of time is revealed thanks to psychoanalytical tools used in Leder's work.

The repressed memory haunted by nightmares or the unsquatted time are - to my mind - probable reasons for growing popularity of Catholic fanatics and nationalist. They do not feel at home, they do not feel embedded in their own society structures. That is why they use "gender" (and in fact any sign of difference) as a sort of foreign attack on the Polish society, that is why they present feminist or queer researchers and activists as jeopardizing Polish social structures.

It is not enough to analyze the conflict that aroused around gender with reference to opposition us-them (with all the possible variations of it), but this way of presenting the conflict also attests to the fact that oppositions, such as the one mentioned, between we and they, are re-established again and again, introduced anew, and used differently for various political goals and strategies. This opposition is introduced in a far right discourse as a tool mobilizing and boosting political activism, but it may be also put in different context and performed with different objectives. Oppositions may moreover be seen as the cuts introduced to the body of society, cuts around which the proliferation and propagation of different forms of expression, solutions to conflicts and factors that preserve it take place. Let us capture and reformulate oppositions to conceptualize it as "unruly edges", productive "seams of empire" (Tsing 2012), burning cuts mobilizing proliferation of bodies, discourses, conflicts, ideas. In this gesture I repeat the oppositional cut introduced in anti-gender discourse on the one hand, but on the other, I am doing so with the aim of depriving it of distance formed in the space between "us" and "them", presenting it more as a site of ongoing conflicts that inhabit this space, with the aim to populate the no-man's-land with a plethora of factors and agents.

To present anti-gender conflict using the lens of psychoanalytical tools as introduced in Leder's book opens it up towards a complexity of factors that fashion it, far and foremost towards the work of time, memory, trauma, psychic. But it also enables the perspective that links the bodily fear of crossing the borders of the new, of being contaminated with the strange, outcast, disgust- 
ing abject together with the powers of psychological processes and the dynamics between forgetting and remembering.

Paradoxically, not facing one's past (as an individual and collective) resulted in a fanatic, fossilized and empty identity as Polish nationalist and Catholic. It is too euphemistic to say that this identity "domesticates all signs of difference", it kills all differences. It cherishes the vision of the Polish imaginarium as fixed once and for all and refuses to open up towards the future.

If it may be stated that the subject in times of war crises (such as the World War II) is a nomad par excellence, then in Polish historical conditions the nomad (understood along the lines of Braidotti's take on the nomadism) became her own contradiction. The transitoriness of life, especially due to war time, being not homeless, but preserving the home so that it could be set up everywhere and simultaneously the impossibility to have a real home (because the home one is setting is embedded in the harms of others), the sense of being eradicated, the fluidity and complexity of human relations (the kind of enemyfriend dialectic), it all fueled the strong, fixed identity that emerged out of fear (of oneself, of one's genealogy). The fixation of identity was also enabled by denying the responsibility for one's actions during the war and perceiving oneself as a passive victim and not as an active agent.

That is the reason why I insist on the figure of squatter as a model of transitory subject. The squatter is facing her past in search for gaps, she embraces the past and attempts to find an intermezzo acting on the past. The squatter is a thread interwoven with other threads in a fabric, one that loosens the whole tight fabric creating holes where the new is possible and where the future is unforeseeable and not determined by the past.

How, then, to address the Jewish blind spot in the Polish imaginarium? How to squat the time to open it up towards the future? How to upset the subject position to enable the past to be reworked, to make the response-ability possible, and to perceive past not as determining the present and the future, but as merely providing us with "the raw material" we may transform?

One of the examples of how to do this is, as I believe, the recent theater project carried out by theater director Paweł Passini and artist Patrycja Dołowy, entitled "The Hideout". The project was performed in a private apartment in Powiśle (district in Warsaw), where the viewer is deprived of her distance, her status as an audience, and instead she is immediately engaged in the squatting of memory, as I would call it. The performance is woven out of overheard stories, fragments, remnants, bits and pieces left unsaid, unfinished, being a matter of conjecture rather than a memory incorporated into an official family genealogy. The stories told depict and detect the Jewish traces in people's biographies (including that of both authors), they absorb the stories told by friends, members of families, acquaintances, and viewers, who - moved by 
the play - decide to reveal their own histories. What is really interesting in this process of memory-squatting is the fact that past Jewish (and others) testimonies of being hidden, of survival, of being harmed, cheated, killed, rescued, of an escape, of a new life, of forgetting, remembering and silencing and also of being a persecutor are interwoven with the present situations, feelings, memories, with the present glancing the past. It is not to sink in the past, but to introduce the opportunity of the present and the future not determined by the haunting past, but responding to it along the lines of response-ability. The authors remind participants of the opposition Jews-non-Jews not to reflect on the opposition itself as a trigger of conflict, but to open it, to make it provoke thoughts, associations, memories, to transform it into "unruly edges", to make it proliferate with difficult past conflicts and memories but also new ways of experiencing them.

The play has no definite ending, it goes on, the music plays on and on, and the authors invite others to engage and contribute their voices to the project.

"The Hideout" loosens the official, narrated out loud history (histories) by responding and entering into a dialogue with what was left out of the picture. It creates the space for response-ability in its both meanings: first, for taking responsibility for one's (past) actions, second, for enabling the omitted and excluded ones to take part in the process of responding to the past.

The bodies of the audience and performers are rolled-up, we barely see each other, but we definitely feel each other. Bodies are in pain, they are exposed to being out of their comfort zones, they overlap with other unknown, strange bodies, the smells, the heat, the clamminess repeat the situation of the hideout. At the same time, however, the hideout here serves as a borderline isolating "us" (whose life is worth preserving) from "them" (whose life may be easily crossed out). This borderline starts to tremble, crumble, and burst, and in consequence it reveals a plethora of feelings, states, stances, memories, thoughts, acts, ways of engaging. As a result, the repeated gesture of establishing the opposition (us-them, but also active-passive) is blurred and replaced with a constellation of hidden lines, traits, and positions.

It is along these lines that I see the possibility of politics of squatting that is squatting both time and space. As I believe this provides us with the new frames to think about ethics and politics, about subjects - their passivity and agency. The perspective here depicted does not introduce a time of catharsis as it takes us far away from our comfort zones and far away from the possibility to have a fresh start. It is more about pulsing in a jellyfish manner or breathing (in the rhythm of indrawn breath and exhalation, cramp and relaxation) - the end and the beginning are obscured, the subject is both active and passive (it swims and it floats simultaneously, it makes an effort and it gives up) but the changes, transformations, and metamorphoses of life are ongoing enabling the time of hope to emerge. Squatting both space and time lies in the 
heart of the politics of squatting as presented in this article. It is an activity driven by the longing of other spaces and other times, which embraces the past and allows itself to be open towards the unknown, the yet unthought-of.

\section{Literature}

Barad, K. 2003. Posthumanist Performativity: Toward an Understanding of How Matter Comes to Matter. Signs: Journal of Women in Culture and Society, 28(3): 801-831.

Braidotti, R. 1994. Nomadic Subjects. Embodiment and Sexual Difference in Contemporary Feminist Theory. Cambridge: Columbia University Press.

Butler, J. 1997. Excitable Speech: A Politics of the Performative. New York: Routledge.

Coole, D. \& Frost, S., eds. 2010. New materialisms: Ontology, Agency, and Politics. Durham, London: Duke University Press.

Deleuze, G. \& Foucault, M. 2006. Intellectuals and Power. A Conversation between Michel Foucault and Gilles Deleuze. Transl. D. Bouchard, S. Simon. URL = $<$ https://libcom.org/library/intellectuals-power-a-conversation-between-michelfoucault-and-gilles-deleuze>, 11.09.2014.

Dolphijn, R. \& van der Tuin, I. 2012. New Materialism: Interviews and Cartographies. Ann Arbor: Open Humanities Press.

Foucault, M. 1984. Of Other Spaces: Utopias and Heterotopias. Transl. J. Miskowiec. Source: http://web.mit.edu/allanmc/www/foucault1.pdf, 5.01.2015.

Grabowski, J. \& Libionka, D., eds. 2014. Klucze i kasa. O mieniu żydowskim w Polsce pod okupacja niemiecka $i$ we wczesnych latach powojennych 1939-1950. Warszawa: Centrum Badań nad Zagładą Żydów.

Grosz, E. \& Cheah, P. 1998. The Future of Sexual Difference. An Interview with Judith Butler and Drucilla Cornell. Diactritics, Spring: 19-42.

Grosz, E. 1987. Notes Towards a Corporeal Feminism. Australian Feminist Studies, 5: 115.

Grosz, E. 1994. Volatile Bodies: Toward a Corporeal Feminism. Bloomington, Indiana: Indiana University Press.

Grosz, E. 2004. The Nick of Time. Politics, Evolution, and the Untimely. Durham, London: Duke University Press.

Grosz, E. 2005. Time Travels. Feminism, Nature, Power. Durham, London: Duke University Press.

Grosz, E. 2010. Untimeliness of the Feminist Theory. NORA. Nordic Journal of Feminist and Gender Research, 1(18): 48-51.

Grosz, E. 2011. Becoming Undone. Darwinian Reflections on Life, Politics, and Art. Durham, London: Duke University Press.

Haraway, D. 1988. Situated Knowledges: The Science Question in Feminism and the Privilege of Partial Perspective. Feminist Studies, 14(3): 575-599. 
Kováts, E., Põim, M., eds. 2015. Gender as Symbolic Glue. The Position and Role of Conservative and Far Right Parties in the Anti-Gender Mobilizations in Europe. Budapest: Foundation for European Progressive Studies, Friedrich-Ebert-Stiftung.

Leder, A. 2014. Prześniona rewolucja. Ćwiczenie z logiki historycznej. Warszawa: Wydawnictwo Krytyki Politycznej.

Manning, E. 2013. Always More Than One. Individuation's Dance. Durham, London: Duke University Press.

Massumi, B. 2014. What Animals Teach Us About Politics. Durham, London: Duke University Press.

Rich, A. 1986. Notes Towards a Politics of Location. Rich, A. Blood, Bread, and Poetry. Selected Prose 1979-1985: 210-233. New York: W\&W Norton Company.

von Uexküll, J. 2010. A Foray Into the Worlds of Animals and Humans. Transl. J. D. O’Neil. Minneapolis, London: University of Minnesota Press.

Tsing, A. 2012. Unruly Edges. Mushrooms as Companion Species. Source: URL = $<$ http://tsingmushrooms.blogspot.com/>, 2.06.2015. 